HW -67938

UC-25, Metals, Ceramics and Materials

(TID-4500, 16th Ed.)

\title{
THE HEAT TREATMENT OF PLUTONIUM
}

\author{
By
}

\author{
H. R. Gardner \\ Plutonium Metallurgy \\ Reactor and Fuels Research and Development \\ Hanford Laboratories Operation
}

February, 1961
HANFORD ATOMIC PRODUCTS OPERATI ON RICHLAND, WASHINGTON

Work performed under Contract No. AT (45-1)-1350 between the Atomic Energy Commission and General Electric Company

\author{
Printed by/for the U. S. Atomic Energy Commission
}




\section{DISCLAIMER}

This report was prepared as an account of work sponsored by an agency of the United States Government. Neither the United States Government nor any agency Thereof, nor any of their employees, makes any warranty, express or implied, or assumes any legal liability or responsibility for the accuracy, completeness, or usefulness of any information, apparatus, product, or process disclosed, or represents that its use would not infringe privately owned rights. Reference herein to any specific commercial product, process, or service by trade name, trademark, manufacturer, or otherwise does not necessarily constitute or imply its endorsement, recommendation, or favoring by the United States Government or any agency thereof. The views and opinions of authors expressed herein do not necessarily state or reflect those of the United States Government or any agency thereof. 


\section{DISCLAIMER}

Portions of this document may be illegible in electronic image products. Images are produced from the best available original document. 


\section{THE HEAT TREATMENT OF PLUTONIUM}

\section{INTRODUCTION}

The element plutonium is unique among metals in that it has six allotropic forms in the solid state. These have been designated as the alpha, beta, gamma, delta, delta-prime, and epsilon phases. The respective phase transformations occur at approximate temperatures of 122,310 , 319,450 , and $480 \mathrm{C}$ with a melting point at $640 \mathrm{C}$.

With this number of phase transformations it becomes pertinent to consider the effect of heat treatment and cooling rate in the various phases on the microstructure and hardness of plutonium. Initially to determine the effect of a wide range of cooling rates it was decided to employ the Jominy end-quenching technique which is commonly used to study the hardenability of steel.

In addition, since the presence of iron in amounts greater than $500 \mathrm{ppm}$ is common in plutonium and results in a network of the $\mathrm{Pu}-\mathrm{Pu}_{6} \mathrm{Fe}$ eutectic it was decided to study heat treatment effects on two bomb-reduced plutonium buttons with different iron contents. A low-iron button containing $165 \mathrm{ppm}$ Fe and a high-iron button containing 678 ppm Fe were selected for this comparison.

\section{SUMMARY AND CONCLUSIONS}

Two groups of plutonium bars, one group containing $165 \mathrm{ppm}$ iron and the other $678 \mathrm{ppm}$ iron were end-quenched from the beta, gamma, delta, delta-prime and epsilon phases.

In general, cooling rate was found to have three striking effects on microstructure. The alpha grain size was found to decrease with increasing cooling rate during cooling from all phases. Upon cooling high-iron plutonium from the epsilon phase, the size of the $\mathrm{Pu}-\mathrm{Pu}_{6} \mathrm{Fe}$ eutectic network decreases with increasing cooling rate. Cooling high-iron plutonium from temperatures between 413 and $460 \mathrm{C}$ produces a wide variety of $\mathrm{Pu}-\mathrm{Pu}_{6} \mathrm{Fe}$ configurations in the microstructure. Finally, the size of an unidentified spheroidal inclusion, 
soluble in the delta and higher temperature phases, decreases as cooling rate increases across the delta to gamma transformation. The above effects of cooling rate can be used to indicate the cooling rate or thermal history that a particular plutonium specimen has encountered.

A linear relationship between the alpha grain size and the $\mathrm{Pu}-\mathrm{Pu}_{6} \mathrm{Fe}$ eutectic network size was observed. The network size is roughly two times larger than the alpha grain size.

Hardness traverses on each of the bars indicated no apparent effect of cooling rate during quenching on hardness.

A density decrease was noted near the quenched end of both low and highiron bars which indicates that faster cooling rates promote microcracking. However, a greater decrease in density was obtained for the low-iron bars which was attributed to their greater tendency to microcrack. The presence of the $\mathrm{Pu}-\mathrm{Pu}_{6} \mathrm{Fe}$ eutectic network in the high-iron bars inhibits microcracking.

EXPERIMENTAL PROCEDURE

Experimental Material

The cylindrical bars for Jominy quenching were cast from button stock in vacuo in MgO coated graphite molds. Metal pouring temperature was approximately $950 \mathrm{C}$ and the molds were preheated to $300 \mathrm{C}$ prior to pouring. After removal from the mold the specimens were cold treated at - $34 \mathrm{C}$ for 24 hours and then machined to 0.5 inch diameter by 2.5 inch long cylinders.

Chemical analysis and density data for the two groups of Jominy specimens containing different iron contents are presented in Table I. Except for iron the two groups are comparable within the limits of analytical accuracy. 


\section{TABLE I}

\section{CHEMICAL ANALYSIS ${ }^{(1)}$ AND DENSITY DATA}

Total

Casting

Excluding Density

\begin{tabular}{|c|c|c|c|c|c|c|c|c|c|c|c|c|c|}
\hline eat & $\mathrm{Al}$ & $\mathrm{Ca}$ & $\mathrm{Cr}$ & $\mathrm{Cu}$ & $\mathrm{Fe}$ & $\mathrm{Mg}$ & $\mathrm{Mn}$ & $\mathrm{Ni} \mathrm{Si}$ & $\underline{\mathrm{Zn}}$ & C & Total & Iron & $(g / c c)$ \\
\hline- & & 2 & 100 & 50 & $67 \varepsilon$ & 5 & 50 & $100<1$ & 50 & 60 & 112 & 450 & 19 \\
\hline$-2-1$ & 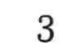 & 3 & 10 & $<5$ & 16 & 20 & 50 & 20 & $<50$ & 50 & 381 & 216 & 19.66 \\
\hline
\end{tabular}

(1) Reported in parts per million.

Representative specimens from the low-iron and high-iron bars were taken for metallographic examination. The low-iron specimen was found to have extensive microcracking (Figure 1). In addition, numerous unidentified spheroidal inclusions were present (Figure 18). The average grain size of the low-iron plutonium is $0.068 \mathrm{~mm}$ (Figure 5). In the high-iron plutonium, a $\mathrm{Pu}-\mathrm{Pu}_{6} \mathrm{Fe}$ eutectic network is prominent (Figure 8). The average size of the network is $0.100 \mathrm{~mm}$. Unidentified spheroidal inclusions were also common in the high-iron plutonium. The average grain size of the high-iron plutonium is $0.036 \mathrm{~mm}$.

Experimental Technique

A Jominy end-quenching fixture was fabricated for glove box use (Figure 2). A 2.5-inch water height was used with an orifice of 0.250 inch ID. The orifice to specimen distance was maintained at 0.5 inch. To obtain cooling curves during end-quenching, radial holes 0.040 inch in diameter by $1 / 8$ to $1 / 4$ inch deep for thermocouples were drilled at distances from the quenched end of $1 / 16,1 / 8,3 / 8,3 / 4,1-1 / 4$, and 2 inches. Chromel-alumel thermocouples were peened into each hole prior to heat treatment. Cooling curves were recorded on three strip chart recorders with 0.25 second full scale response times and chart speeds of 6, 12, and 20 inches/minute. The temperature scale on each recorder was adjusted to obtain maximum sensitivity over the temperature range covered by each quench. 
Annealing temperatures of $160,265,400,465$, and $535 \mathrm{C}$ were chosen for the study of the effect of quenching from the beta, gamma, delta, deltaprime, and epsilon phases on microstructure and hardness. At the 160 and $265 \mathrm{C}$ temperatures an agitated peanut oil bath was used for annealing. For the higher temperatures a $50: 50 \mathrm{NaNO}_{2}-\mathrm{KNO}_{3}$ salt bath was used. Annealing times ranged from 25 to 65 minutes in the oil bath while in the salt bath a 5 minute time was used. The quench water temperature ranged from 5-10 C.

From the cooling curves obtained, cooling rate calculations were made for temperature intervals of 100-110, 160-170,330-340,420-430, and 490-500 C. These temperature intervals were chosen for their proximity to transformation temperatures because it was felt that they would be critical for determining the effect of cooling rate on structure. The cooling rate versus distance from the quenched end curves for each annealing temperature are presented in the Appendix.

After end-quenching, parallel flats for hardness testing were milled 0.015 deep on each specimen. Hardness traverses were made at $1 / 16$ inch intervals for the first $1 / 2$ to $3 / 4$ inch and at $1 / 8$ inch intervals for the rest of the bar. Hardness testing was done on a glove boxed Tukon Hardness Tester using a 136 degree diamond indentor and a $10 \mathrm{~kg}$ load.

After hardness testing each specimen was cut into three equal sections. A density determination was made on the section including the quenched end of the bar. All sections were mounted in cold setting resin for metallographic study. The metallographic specimen preparation procedure is described elsewhere.

\section{$\underline{\text { Results and Discussion }}$}

During the metallographic studies on the end-quenched Jominy specimens three striking effects on microstructure were observed. The alpha grain size, the configuration of the $\mathrm{Pu}-\mathrm{Pu}_{6} \mathrm{Fe}$ eutectic network and the size of an unidentified spheroidal inclusion were all markedly affected by cooling rate. 
The effect of cooling rate on alpha grain size as indicated by distance from the quenched end of the Jominy specimens is illustrated in Table II. If distance from the quenched end is translated into cooling rate by means of the cooling rate curves in the Appendix, it is possible to graph grain size as a function of cooling rate. This relationship is illustrated in Figure 3 for cooling rates determined in temperature intervals of 100-110 C, 160-170 C, 330-340 C and 490-500 C while quenching from the beta, gamma, delta and epsilon phases respectively. From Table II and the above figure it is evident that for all phases grain size increases as cooling rate decreases, i.e., as distance from the quenched end increases. In addition, the effect of increasing the annealing temperature prior to end-quenching is to decrease the grain size at a particular position in the Jominy specimens. For example, at the quenched end of the Jominy specimens, the marked decrease in grain size as annealing temperature increases is illustrated in Figure 4.

Photomicrographs illustrating the effect of cooling rate on grain size for specimens end-quenched from the beta, gamma, delta, and epsilon phases are presented in Figures 5 and 6 . Note that the grains present in the beta quenched specimen are very nonuniform in size and shape while those in the specimens quenched from higher temperatures are relatively uniform and equiaxed.

The second effect of cooling rate on microstructure concerns the configuration of the $\mathrm{Pu}-\mathrm{Pu}_{6} \mathrm{Fe}$ eutectic network in the high-iron Jominy specimens. Since the eutectic between $\mathrm{Pu}$ and $\mathrm{Pu}_{6} \mathrm{Fe}$ melts at $413 \mathrm{C}$ it was expected that this would be a critical temperature for heat treatment studies. In addition, the British work on the plutonium-iron phase diagram by Mardon, Haines and Pearce ${ }^{(2)}$ (Figure 7), indicated that a variety of substantially different structural configurations of the $\mathrm{Pu}-\mathrm{Pu}{ }_{6} \mathrm{Fe}$ eutectic could be obtained by heat treating at various temperatures above $413 \mathrm{C}$.

In the high-iron Jominy specimen quenched from $527 \mathrm{C}$ in the epsilon phase it was found that the eutectic network size was $0.003 \mathrm{~mm}$ in diameter at the quenched end and increased by a factor of 10 to $0.035 \mathrm{~mm}$ as cooling 
TABLE II

ALPHA GRAIN SIZE VERSUS DISTANCE FROM QUENCHED END OF JOMINY SPECIMENS

Specimen Num

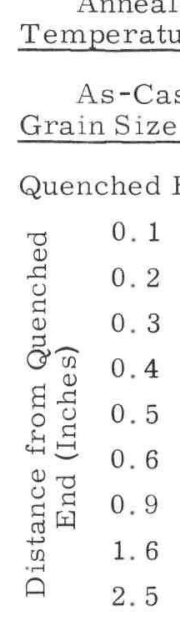

\begin{abstract}
19-12-1A
$20-2-1 L$
\end{abstract}

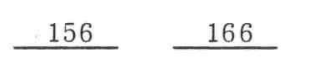

0.010

0.012

--

0.013

$$
-
$$$$
--
$$

0.020

$--$

(1)

(1)

\begin{tabular}{|c|c|}
\hline 0.036 & 0.06 \\
\hline 0.008 & 0.010 \\
\hline 0.015 & -- \\
\hline-- & 0.014 \\
\hline 0.020 & -- \\
\hline 0.020 & 0.027 \\
\hline-- & -- \\
\hline 0.020 & 0.035 \\
\hline -- & 0.040 \\
\hline 0.024 & 0.040 \\
\hline 0.024 & 0.040 \\
\hline
\end{tabular}

$19-12-1 \mathrm{H}$

$\underline{20-2-10}$

(1) Wide range of grain sized present, not possible to get good estimate.

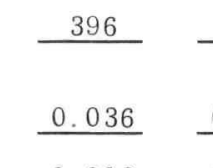

0.003

0.007

$--$

0.009

$--$

0.013

--

0.014

0.020

0.020

420

473

465

533

537

$\frac{0.068}{0.003} \quad \frac{0.036}{0.002}$

$\frac{0.068}{0.002}$

$\frac{0.036}{0.001}$

0.068

$--$

0.006

$--$

0.003

0.001

0.002

0.008

0.012

$0.010 \quad 0.009$

--

0.009

0.009

0.012

$0.014 \quad 0.014$

0.012

0.014

0.010

$0.014 \quad 0.010$

$0.014 \quad 0.010$

$--$

0.020

--

0.024

0.024

0.014
0.014
0.012

.

24


rate decreased along the length of the specimen (Figure 8). The original as-cast network size was $0.100 \mathrm{~mm}$. Graphically the relation between cooling rate and eutectic network size is illustrated in Figure 9. The process by which the network forms is a eutectoidal decomposition of the epsilon phase at $430 \mathrm{C}$ to delta plutonium plus a liquid which is distributed around the islands of delta plutonium. The liquid network further decomposes in a eutectic reaction at $413 \mathrm{C}$ to delta plutonium plus $\mathrm{Pu}_{6} \mathrm{Fe}$.

To further explore the effect of heat treatment temperature on eutectic configuration, the temperature ranges of 430 to $460 \mathrm{C}$ and 413 to $430 \mathrm{C}$ were chosen for study from the plutonium-iron phase diagram. Plutonium analyzing $1142 \mathrm{ppm} \mathrm{Fe}$ with an as-cast network size of $0.070 \mathrm{~mm}$ was used for this phase of the work (Figure 10).

Between 430 and $460 \mathrm{C}$ in the delta plus epsilon phase region, quenching results in a mixture of islands of plutonium plus islands of a fine network of the $\mathrm{Pu}-\mathrm{Pu}_{6} \mathrm{Fe}$ eutectic (Figures 11 and 12). The islands of fine eutectic network are obtained during the eutectoidal decomposition of the epsilon phase. The variation in network size between the structures illustrated in Figures 11 and 12 is the result of a variation in cooling rate during quenching. The somewhat coarser network in Figure 12 was caused by a slower cooling rate during quenching.

Between 413 and $430 \mathrm{C}$, the stable phases are delta plutonium plus liquid. The structure obtained on quenching from this temperature is illustrated in Figure 13. The large islands are agglomerated $\mathrm{Pu}-\mathrm{Pu}{ }_{6} \mathrm{Fe}$, the matrix is transformed delta, i.e., alpha plutonium.

The effect of a slow cool at $2.7 \mathrm{C} / \mathrm{hr}$ from temperatures above $460 \mathrm{C}$ on the $\mathrm{Pu}-\mathrm{Pu}_{6} \mathrm{Fe}$ eutectic network is illustrated in Figure 14. The network is approximately $0.3 \mathrm{~mm}$ in average diameter. This result is graphed on Figure 9. Note the islands of alpha plutonium apparent in the $\mathrm{Pu}_{6} \mathrm{Fe}$ matrix of the network.

During the course of this wo rk it was determined that the $\mathrm{Pu}-\mathrm{Pu}_{6} \mathrm{Fe}$ eutectic network willspheroidize in either the gamma phase or delta phase 
below $413 \mathrm{C}$. (Figures 15 and 16). Note the boundaries of equiaxed grains apparent in Figure 16 where the speroidized $\mathrm{Pu}-\mathrm{Pu}_{6} \mathrm{Fe}$ inclusions appear as dark circular areas as the result of a longer etching time than used for the specimen in Figure 15. The equiaxed grains are the grains present in the delta phase at the $400 \mathrm{C}$ annealing temperature used for this specimen which was quenched after annealing. They average $0.050 \mathrm{~mm}$ in diameter compared to an alpha grain size of $0.010 \mathrm{~mm}$ as viewed under polarized illumination. Thus the grain size has been refined by a factor of five during quenching through the subsequent phase transformations to room temperature.

In the Jominy and other experimental specimens containing the Pu$\mathrm{Pu}_{6} \mathrm{Fe}$ eutectic network which were continuously cooled from the epsilon phase, it is possible to determine the relation between the grain size outlined by the network and the alpha grain size of plutonium. A linear relation is obtained (Figure 17). Algebraically the relation is expressed by the equation $\mathrm{y}=2.25 \mathrm{x}+0.0032$ where $\mathrm{y}$ is the network size and $\mathrm{x}$ is the alpha grain size. Thus the alpha grain size is always finer than the network size by roughly a factor of 2 . Since the network size is actually the grain size present in the epsilon phase, it is evident that the additional alpha grain refinement takes place during subsequent lower temperature phase transformation.

It is pertinent to note that in high-iron plutonium, the existing network size or $\mathrm{Pu}-\mathrm{Pu}{ }_{6} \mathrm{Fe}$ configuration can be used as an indication of the thermal history, i.e., cooling rate, or control thereof during casting or heat treatment.

Considering the variation in configuration of the $\mathrm{Pu}-\mathrm{Pu}{ }_{6} \mathrm{Fe}$ eutectic network which can be obtained by heat treatment, it would not be surprising if significant affects on properties could be produced by heat treatment of plutonium containing 500-1500 ppm Fe.

A third significant metallographic feature was observed in the Jominy bars quenched from the delta and higher temperature phases. The size of an unidentified spheroidal inclusion was observed to vary with cooling rate 
(Figure 18). It was subsequently determined that this inclusion is soluble in the delta and higher temperature phases of plutonium. During quenching to room temperature the inclusion precipitates and its size is influenced by cooling rate. Inclusions of this type have been grown as large as 0.001 inches by cooling at $2.7 \mathrm{C} / \mathrm{hr}$ across the delta to gamma transformation. It has also been determined that this type of inclusion will preferentially precipitate at carbide and nitride inclusions (Figure 19). Considering the spheroidal shape of this inclusion it is not probable that it will produce any great effect on the properties of plutonium.

Hardness traverses made along the length of specimens end-quenched from all phases did not indicate a significant effect of either annealing temperature, or cooling rate on hardness (Figure 20). This was true of both low-iron and high-iron plutonium. There was more scatter in the low-iron hardness data and this was attributed to the much greater frequency of microcracking in the low-iron plutonium (Figure 1). The high-iron plutonium was practically mocrocrack free, because of the microcrack inhibiting action of the $\mathrm{Pu}-\mathrm{Pu}{ }_{6} \mathrm{Fe}$ eutectic. (1)

Since it is believed that most of the microcracking in plutonium occurs during the beta to alpha transformation, the effect of cooling rate on microcracking as indicated by a decrease in density near the quenched end was studied by using the cooling rate at 0.1 inches from the quenched end over a temperature interval of 100-110 C. In Figure 21, the data are presented for both high and low-iron plutonium. As expected, based on the inhibiting effect of the $\mathrm{Pu}-\mathrm{Pu}_{6} \mathrm{Fe}$ eutectic on microcracking, the low-iron specimens had the greatest decrease in density indicating a greater number and/or size of microcracks. 
HW - 67938

\section{REFERENCES}

1. Gardner, H. R. and I. B. Mann. "Mechanical Property and Formability Studies on Unalloyed Plutonium, " Paper No. 36. Second International Conference on Plutonium, (Grenoble, France), April 19-22, 1960.

2. Mardon, P. G., H. R. Haines and J. H. Pearce. "The PlutoniumIron System" . Journal of the Institute of Metals, Vol. 86. 1957-58.

\section{ACKNOWLEDGEMENT}

The outstanding performance of I. B. Mann on the varied procedures used to conduct this study a re greatly appreciated. In addition the author wishes to express his gratitude to J. P. Keiser, W. B. Leahy, and I. M. Glover for their fine work in metallography, machining and photo processing. 


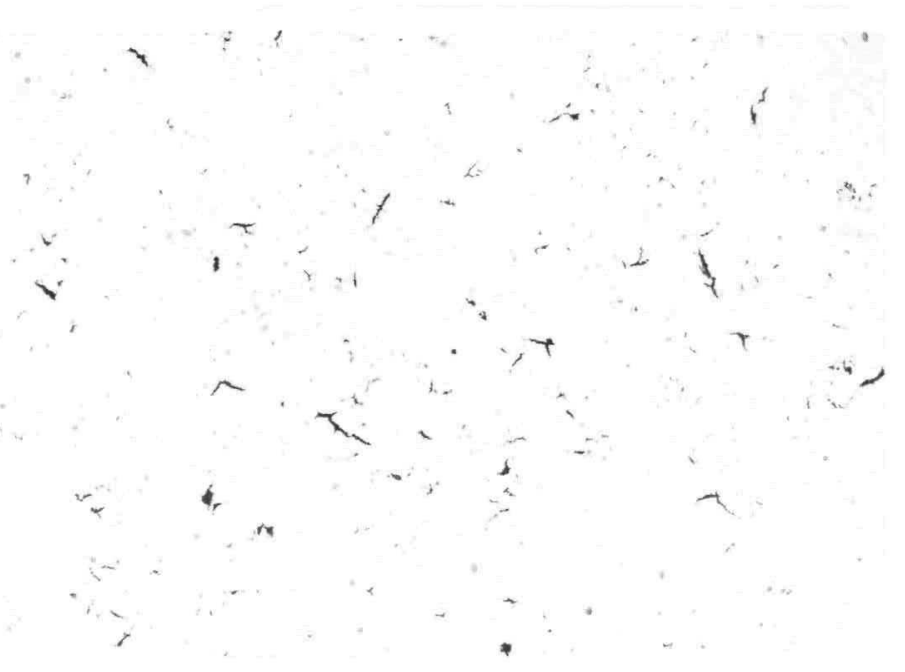

\section{FIGURE 1}

$50 \mathrm{X}$

Microcracking Present in Low-Iron Plutonium, 165 ppm Fe

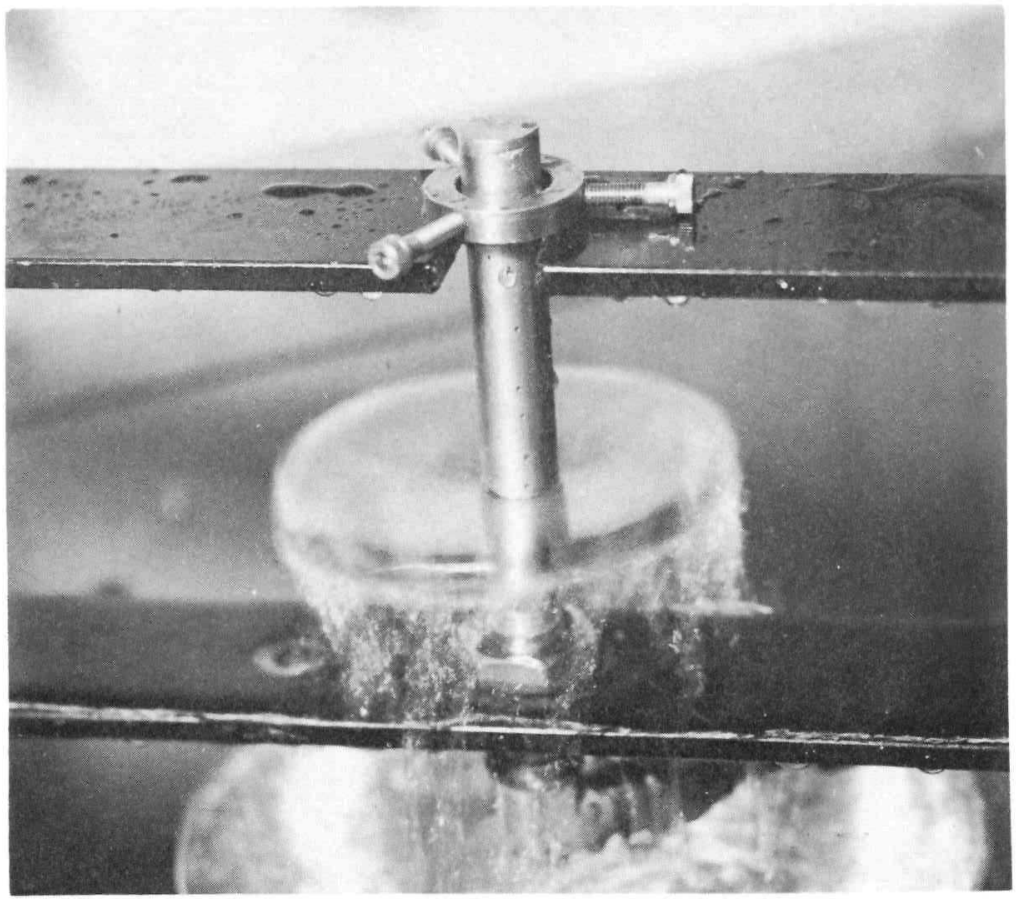

$1 / 2 X$

FIGURE 2

Apparatus for End-Quenching Plutonium 


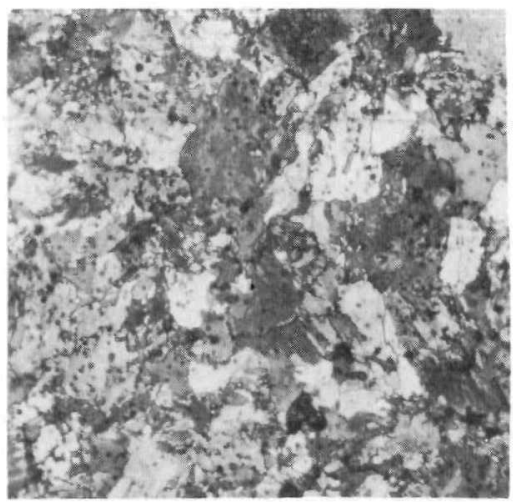

As-Cast $0.068 \mathrm{~mm}$

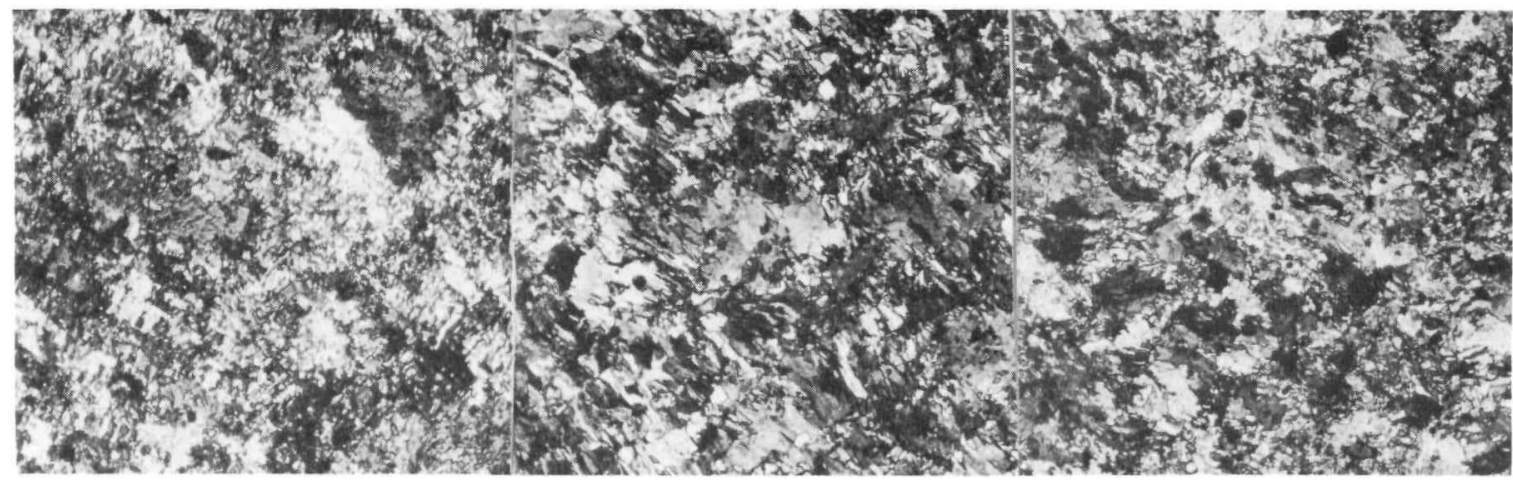

Quenched End $123 \mathrm{C} / \mathrm{min}$ $27 \mathrm{C} / \mathrm{min}$

End-Quenched from $160 \mathrm{C}$ in Beta Phase, Cooling Rate for 100-110 C

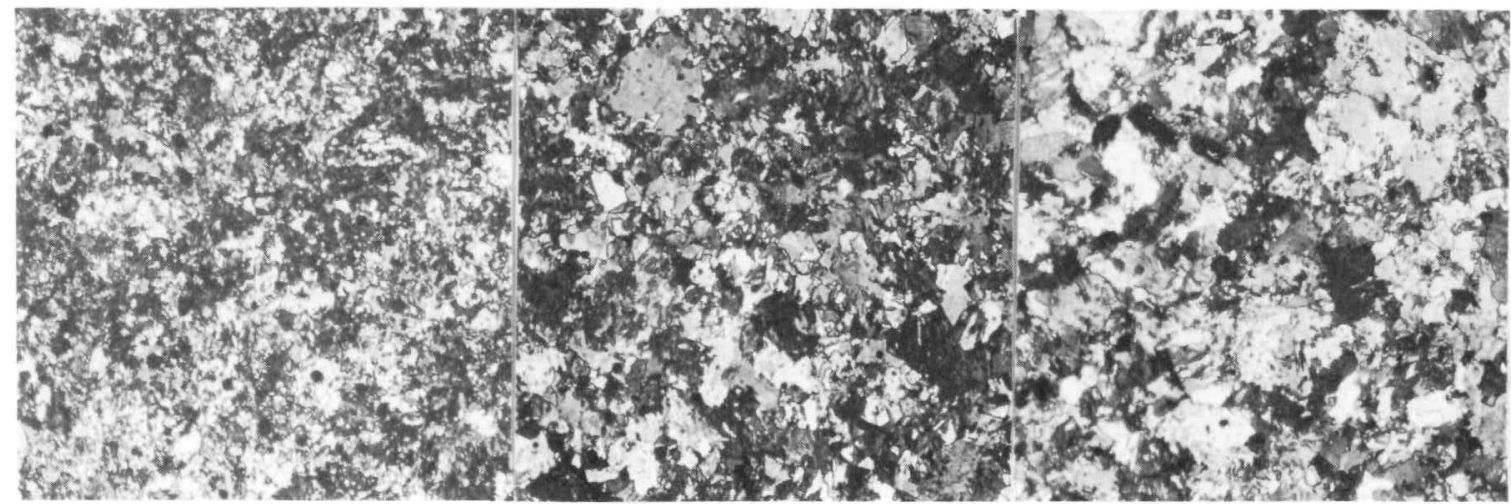
Quenched End
$130 \mathrm{C} / \mathrm{min}$
$48 \mathrm{C} / \mathrm{min}$
$0.010 \mathrm{~mm}$
$0.037 \mathrm{~mm}$
$0.040 \mathrm{~mm}$

End-Quenched from $265 \mathrm{C}$ in Gamma Phase, Cooling Rate for 160-170 C

FIGURE 5

Effect of Cooling Rate on Grain Size for Beta and Gamma Quenches $150 \mathrm{X}$ 


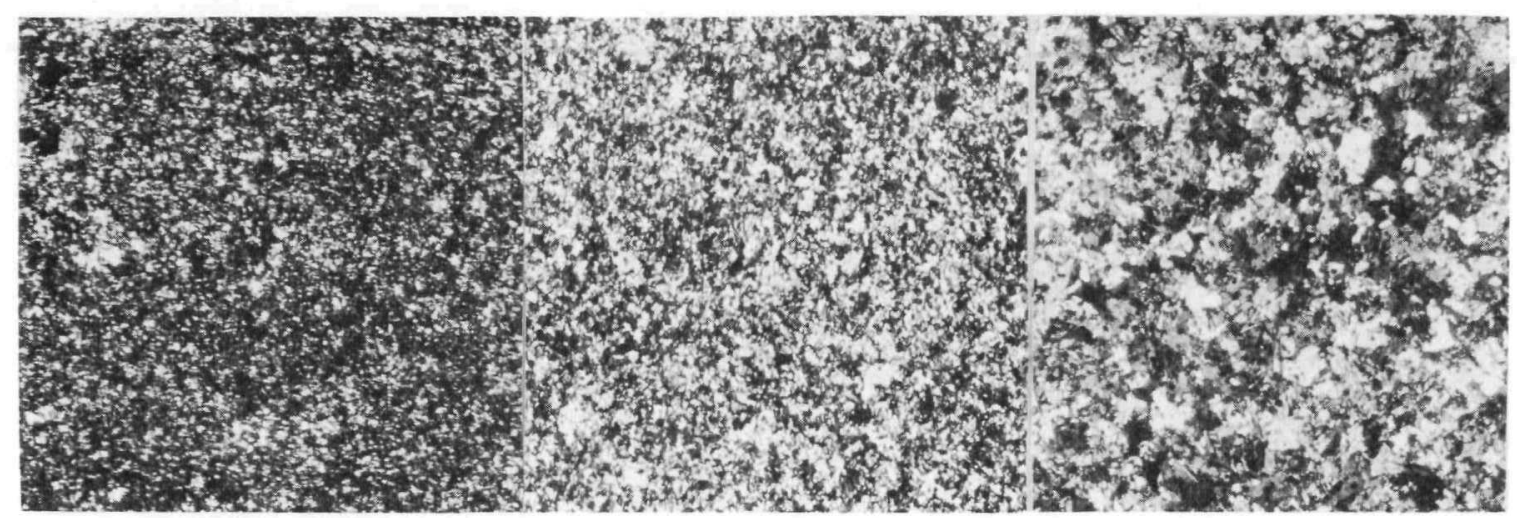
Quenched End
$520 \mathrm{C} / \mathrm{min}$
$143 \mathrm{C} / \mathrm{min}$
$0.003 \mathrm{~mm}$
$0.009 \mathrm{~mm}$
$0.014 \mathrm{~mm}$

End-Quenched from 420 C in Delta Phase, Cooling Rate for 330-340 C

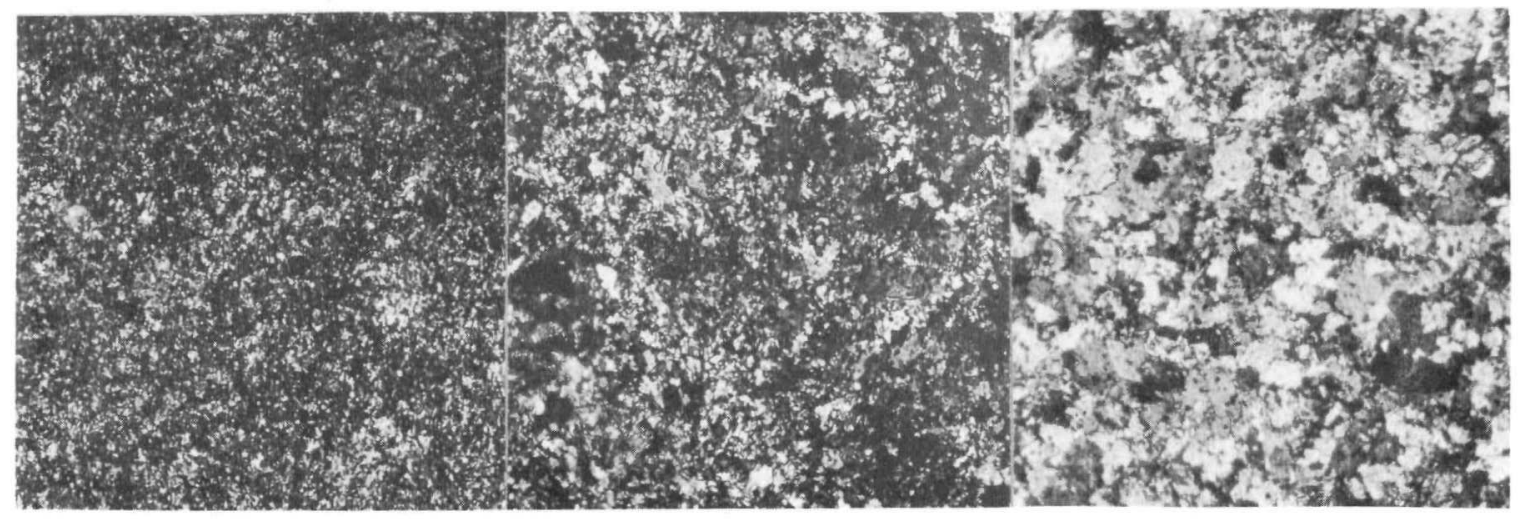
Quenched End
$2300 \mathrm{C} / \mathrm{min}$
$510 \mathrm{C} / \mathrm{min}$
$0.001 \mathrm{~mm}$
$0.008 \mathrm{~mm}$
$0.024 \mathrm{~mm}$

End-Quenched from $535 \mathrm{C}$ in Epsilon Phase, Cooling Rate for 490-500 C

\section{FIGURE 6}

Effect of Cooling Rate on Grain Size for Delta and Epsilon Quenches 


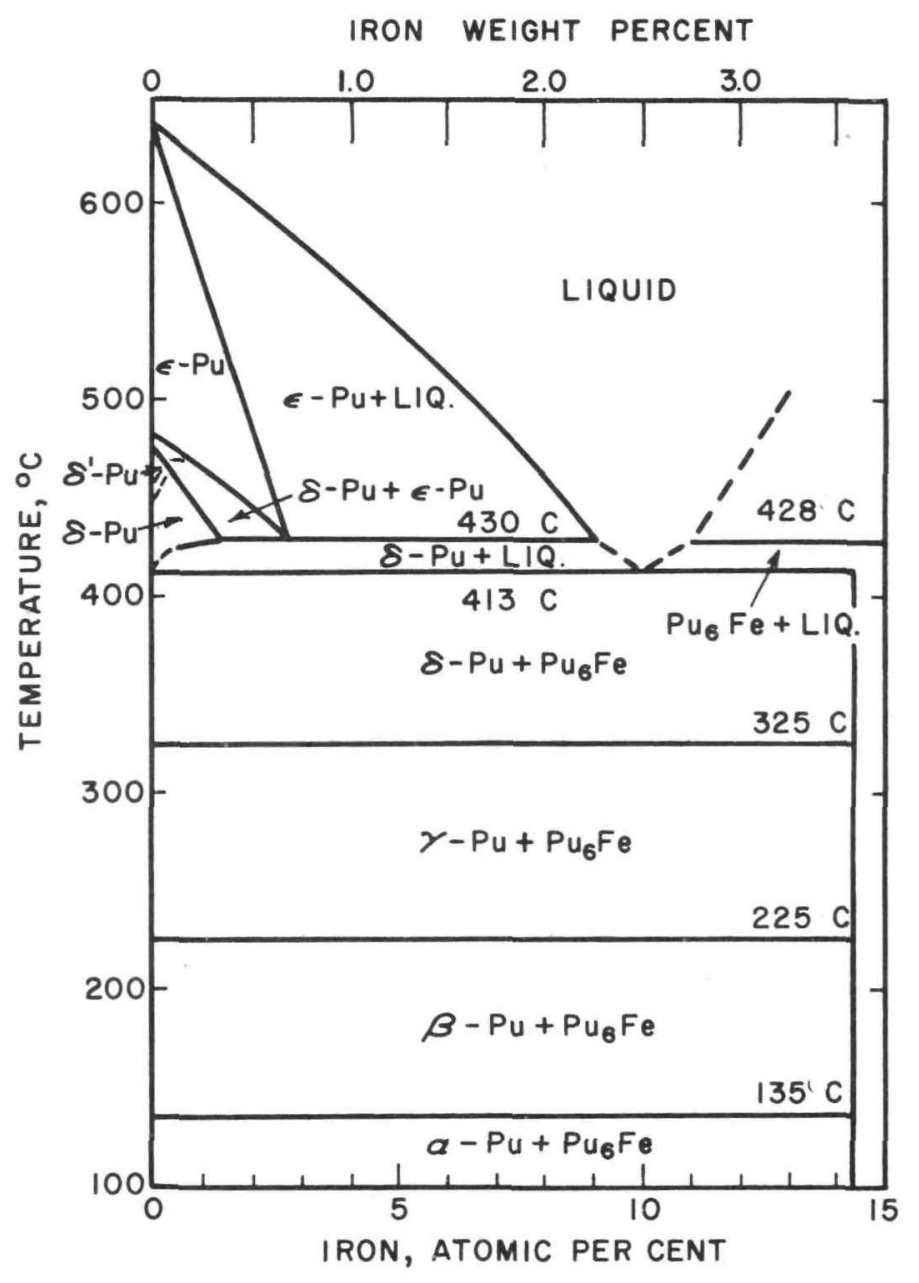

FIGURE 7

The Plutonium-Rich Portion of the Plutonium-Iron Equilibrium Diagram 


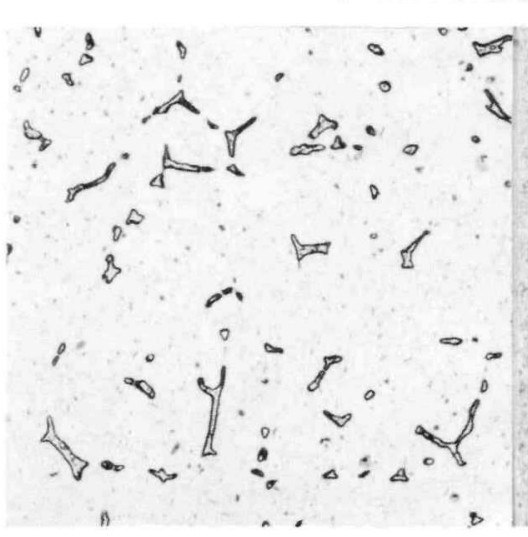

As Cast

$0.100 \mathrm{~mm}$
Quenched End $0.003 \mathrm{~mm}$
$5700 \mathrm{C} / \mathrm{min}$

$0.006 \mathrm{~mm}$

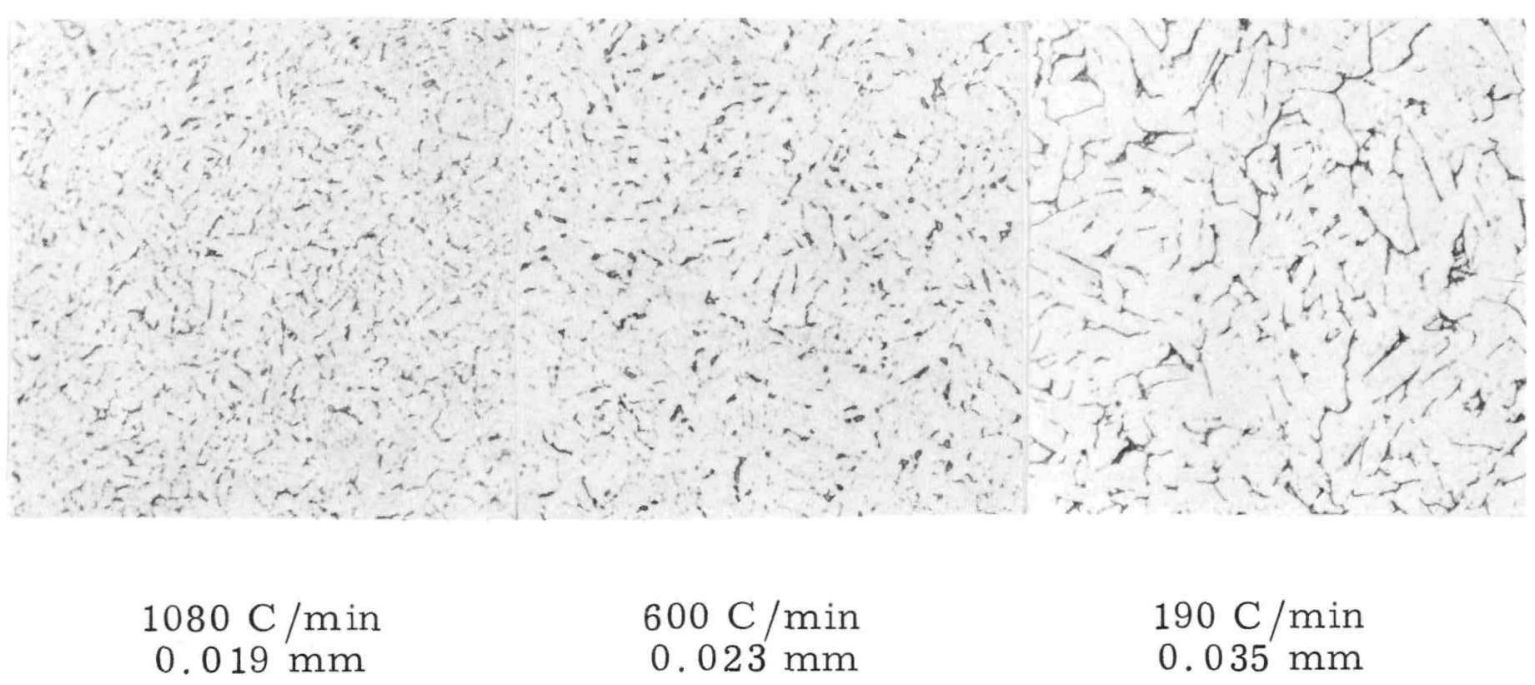

FIGURE 8

Effect of Cooling Rate on Size

of $\mathrm{Pu}-\mathrm{Pu}_{6} \mathrm{Fe}$ Eutectic Network in Plutonium Containing $678 \mathrm{ppm} \mathrm{Fe}$ End Quenched from 533 C, Cooling Rate for 420-430 C 


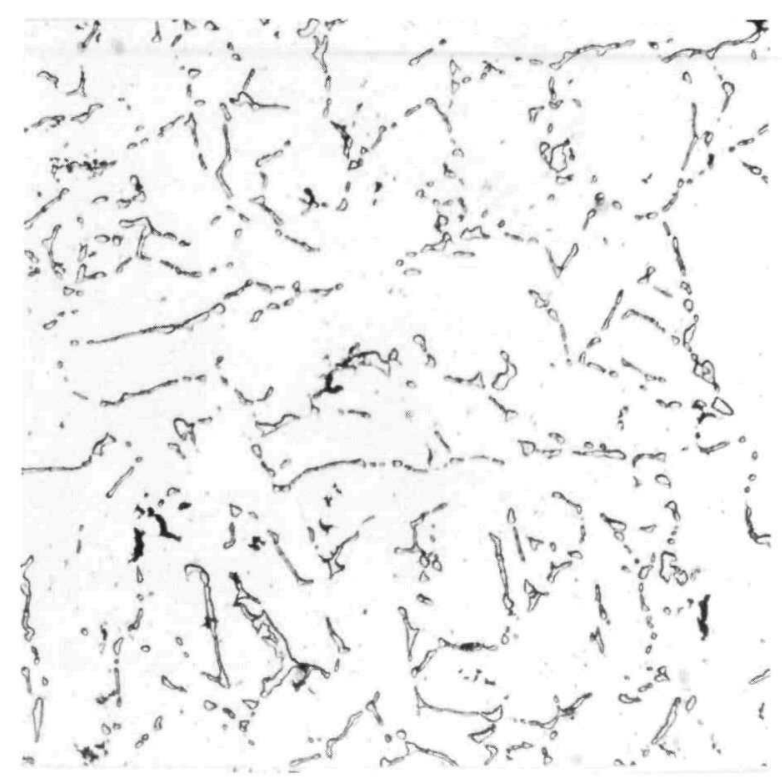

\section{FIGURE 10}

As Cast, 1143 ppm Fe. $\mathrm{Pu}-\mathrm{Pu}_{6} \mathrm{Fe}$ network, $0.070 \mathrm{~mm}$ $150 \mathrm{X}$

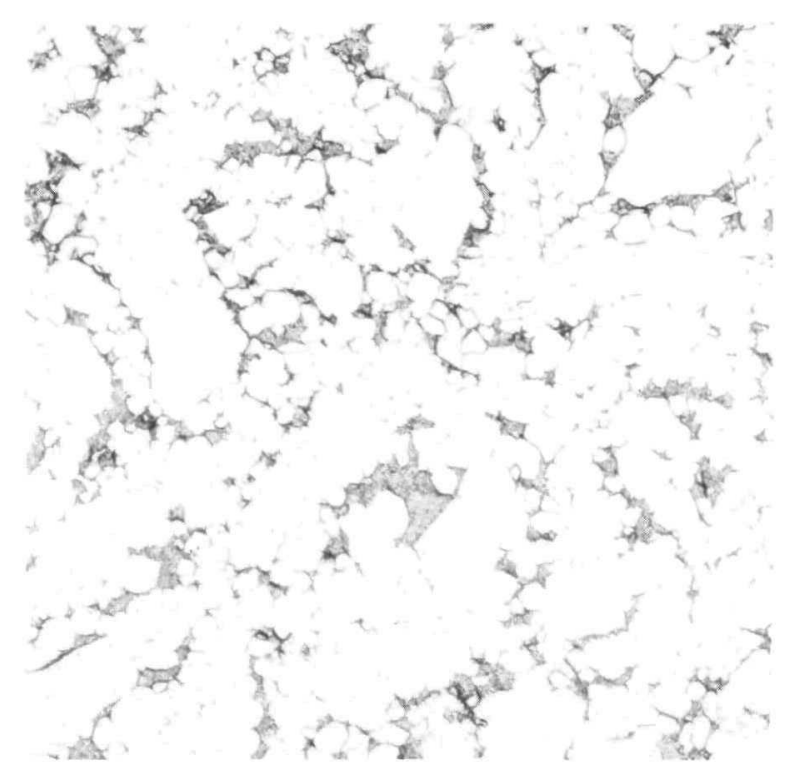

\section{FIGURE 11}

Annealed at $460 \mathrm{C}$ and Water Quenched.

Note Islands of Fine Grained $\mathrm{Pu}-\mathrm{Pu}_{6} \mathrm{Fe}$ Eutectic Network 


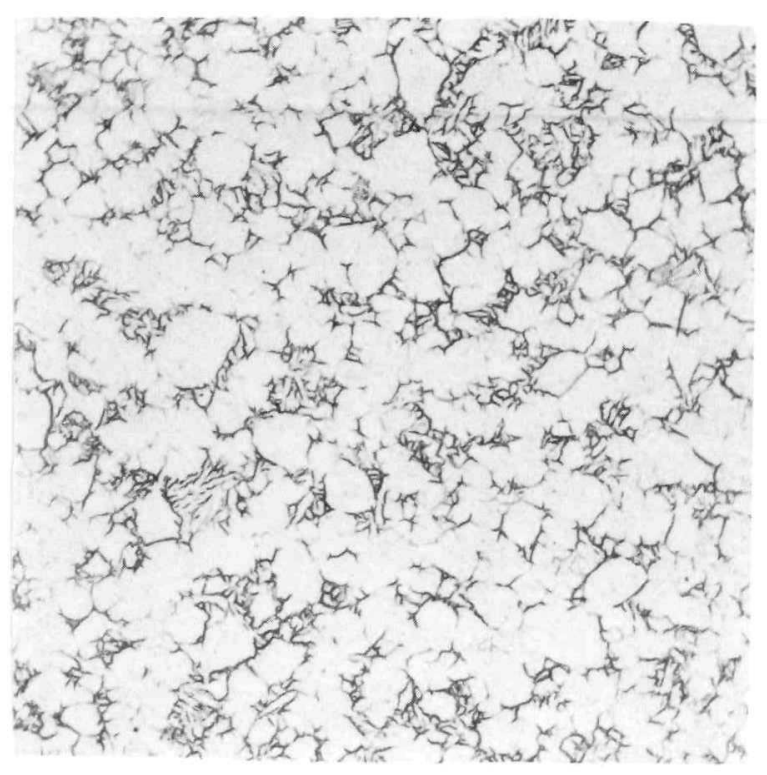

FIGURE 12

$150 \mathrm{X}$

Annealed at $460 \mathrm{C}$ and Air Cooled Briefly Prior to Water Quenching. Islands of $\mathrm{Pu}-\mathrm{Pu}_{6} \mathrm{Fe}$ Eutectic Network Coarser Grained than Preceding Figure

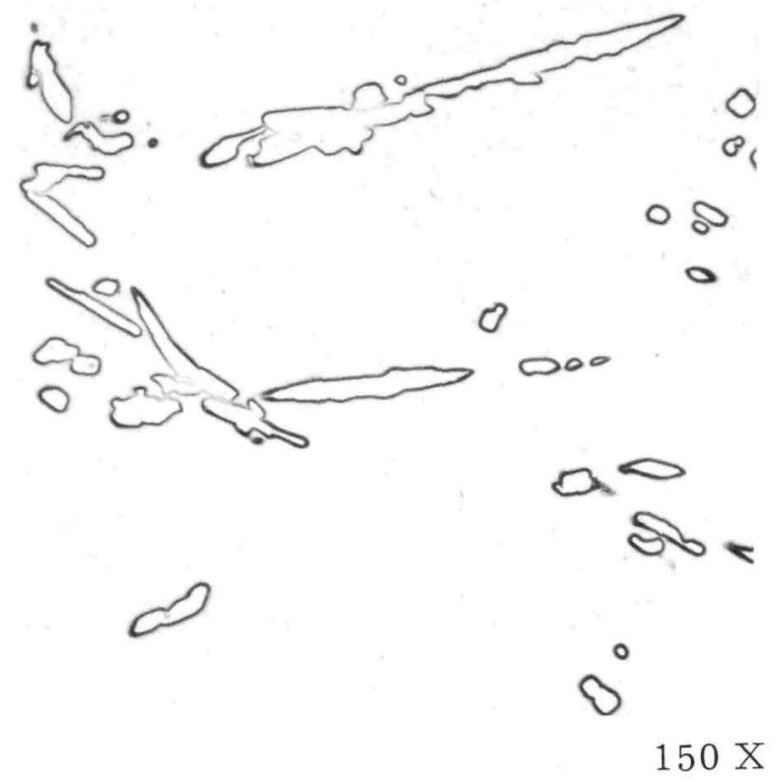

FIGURE 13

Annealed at $430 \mathrm{C}$ and Water Quenched.

Note Islands of $\mathrm{Pu}-\mathrm{Pu}_{6} \mathrm{Fe}$ Eutectic 


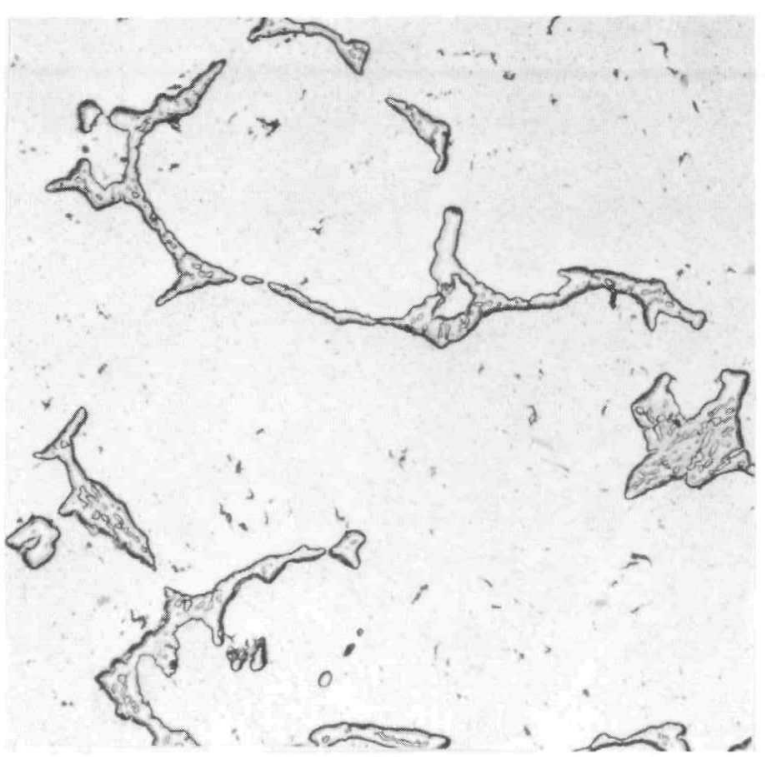

FIGURE 14

Annealed at $500 \mathrm{C}$ for Several Hours and Cooled to $350 \mathrm{C}$ at 2.7 $\mathrm{C} / \mathrm{hr} . \mathrm{Pu}-\mathrm{Pu}_{6} \mathrm{Fe}$ Network Coarse, $0.3 \mathrm{~mm}$ with Substructure Apparent .

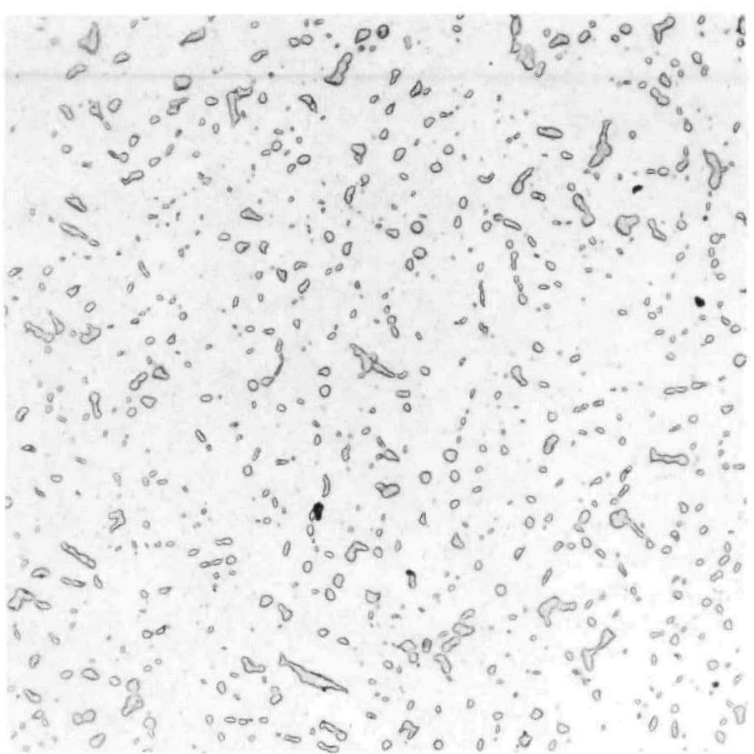

FIGURE 15

Spheroidization of $\mathrm{Pu}-\mathrm{Pu}_{6} \mathrm{Fe}$ Eutectic Obtained During Annealing in Gamma Phase or Delta Phase Below $413 \mathrm{C}$ $150 \mathrm{X}$

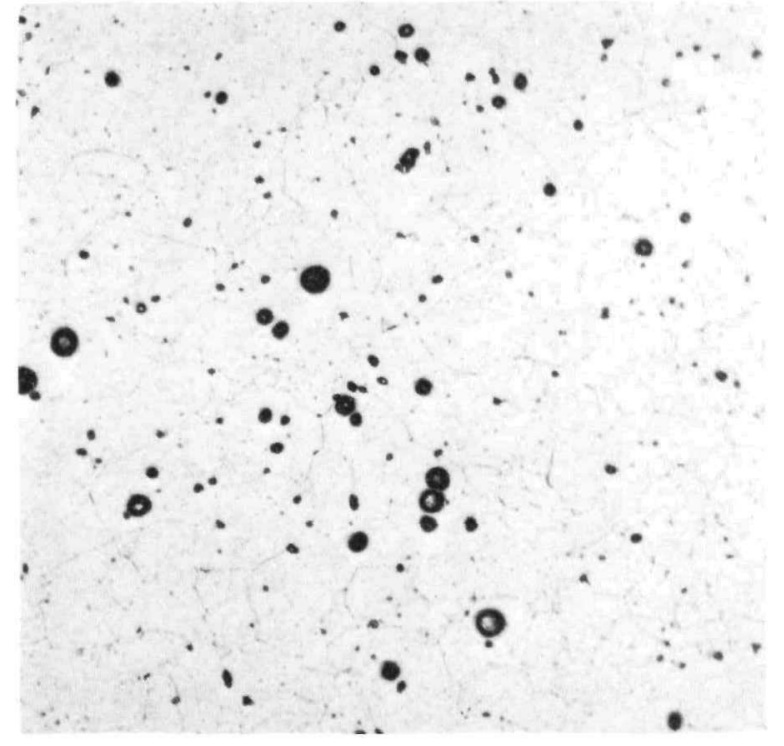

FIGURE 16

Spheroidized $\mathrm{Pu}-\mathrm{Pu}_{6} \mathrm{Fe}$ (dark circles)

Note Boundaries of Equiaxed Grains with Average Grain Size of $0.050 \mathrm{~mm}$ $150 \mathrm{X}$ 


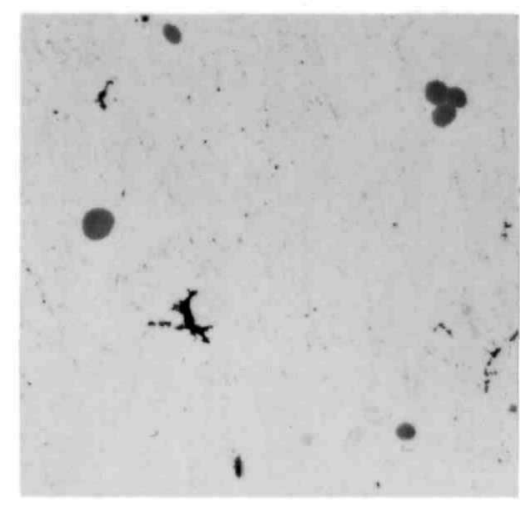

As-Cast

Quenched End

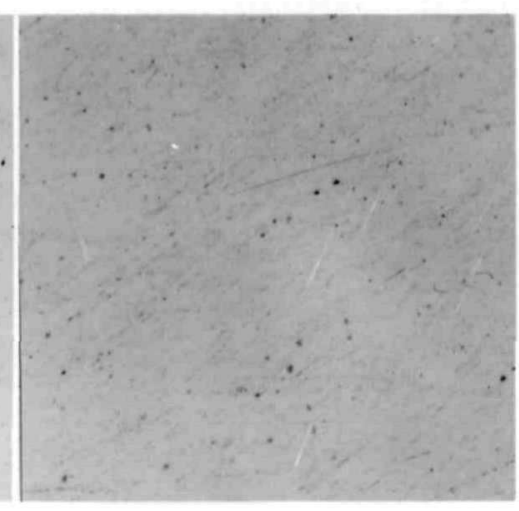

$1600 \mathrm{C} / \mathrm{min}$

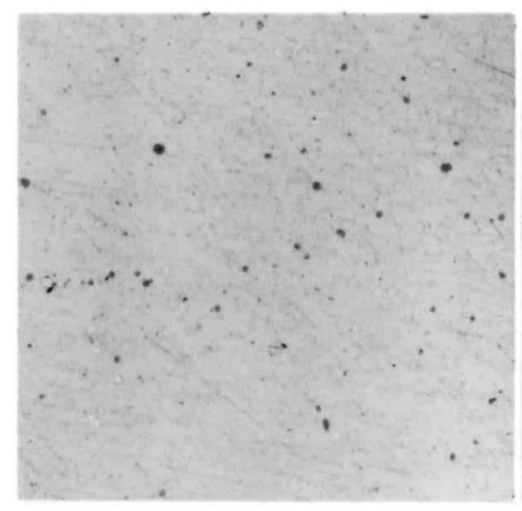

$820 \mathrm{C} / \mathrm{min}$

$375 \mathrm{C} / \mathrm{min}$

$143 \mathrm{C} / \mathrm{min}$

FIGURE 18

Effect of Cooling Rate on Size of Unidentified Spheroidal Inclusions in Plutonium End-Quenched from $420 \mathrm{C}$, Cooling Rate for 330-340 C 


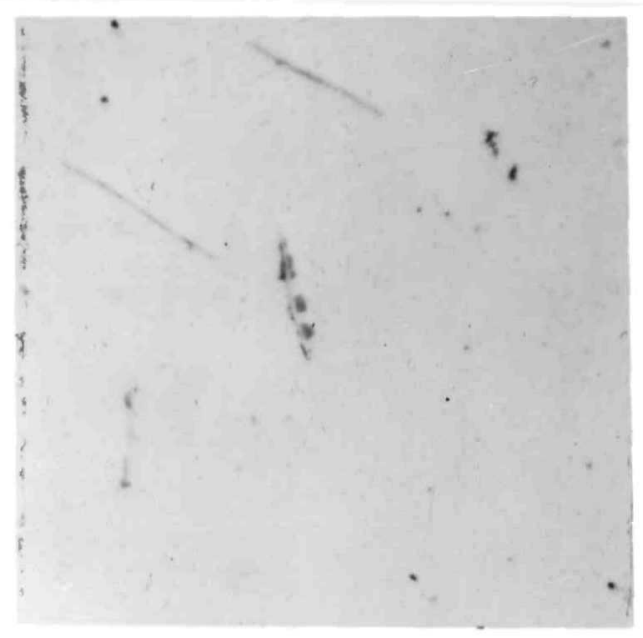

$500 \mathrm{X}$

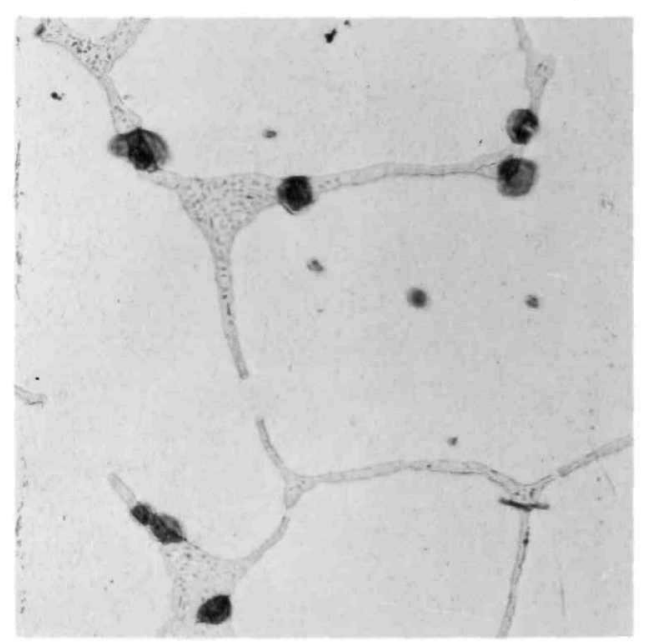

$250 \times$

FIGURE 19

Spheroidal Precipitate Nucleated at Carbide Inclusions (needles) in Upper Photo, and at $\mathrm{Pu}-\mathrm{Pu}_{6} \mathrm{Fe}$ Eutectic Network in Lower Photo
6187,5843 


\section{APPENDIX}

The graphs on the following pages indicate the relationship between cooling rate and distance from the quenched end of the plutonium Jominy specimens. Curves are presented for end-quenching from the beta., gamma, delta and epsilon phases.

Cooling rates were determined at temperature intervals considered to be critical from the standpoint of effect on metallurgical characteristics. 


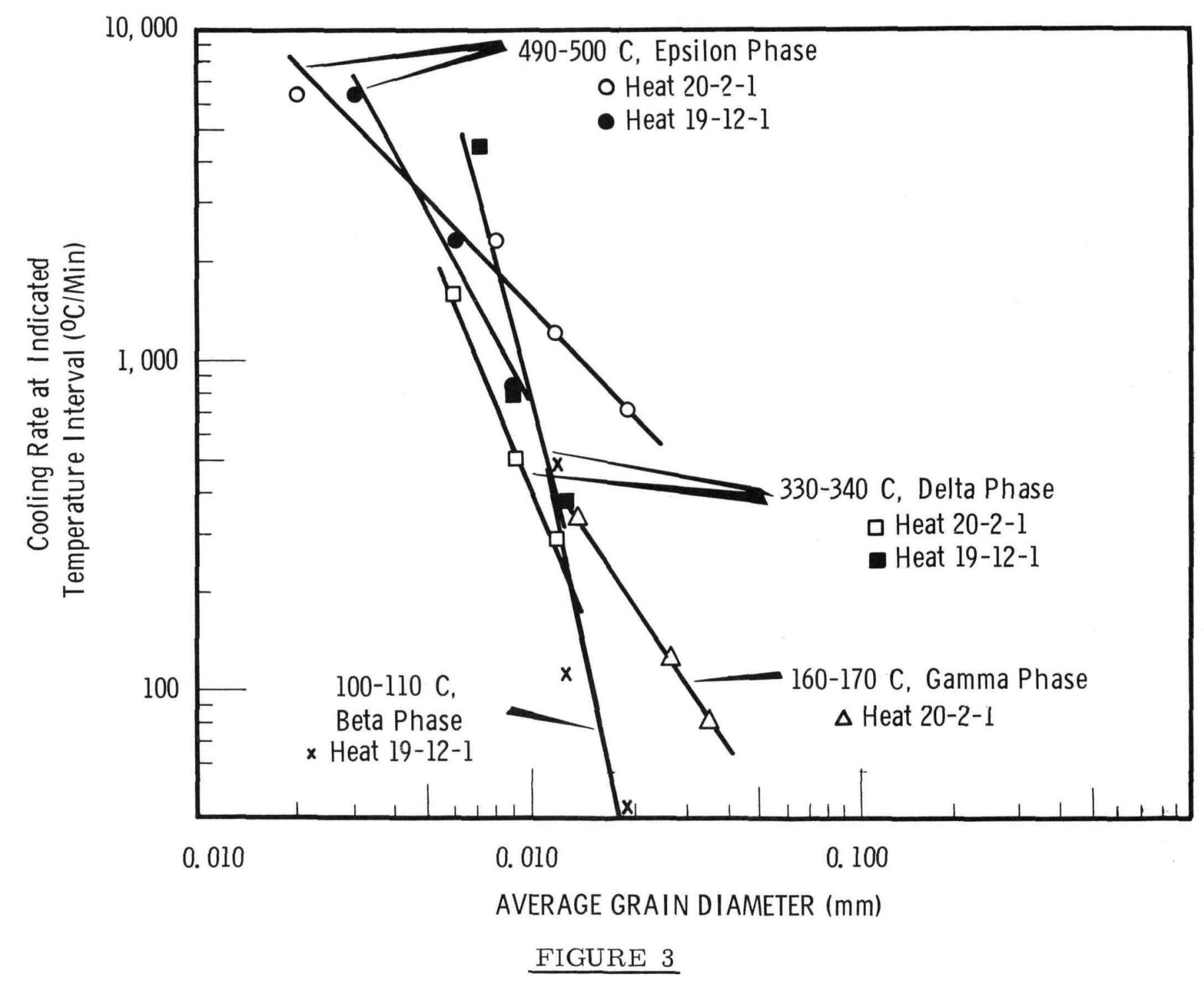

Relation Between Cooling Rate and Alpha Grain Size for End-Quenching from Beta, Gamma, Delta and Epsilon Phases 


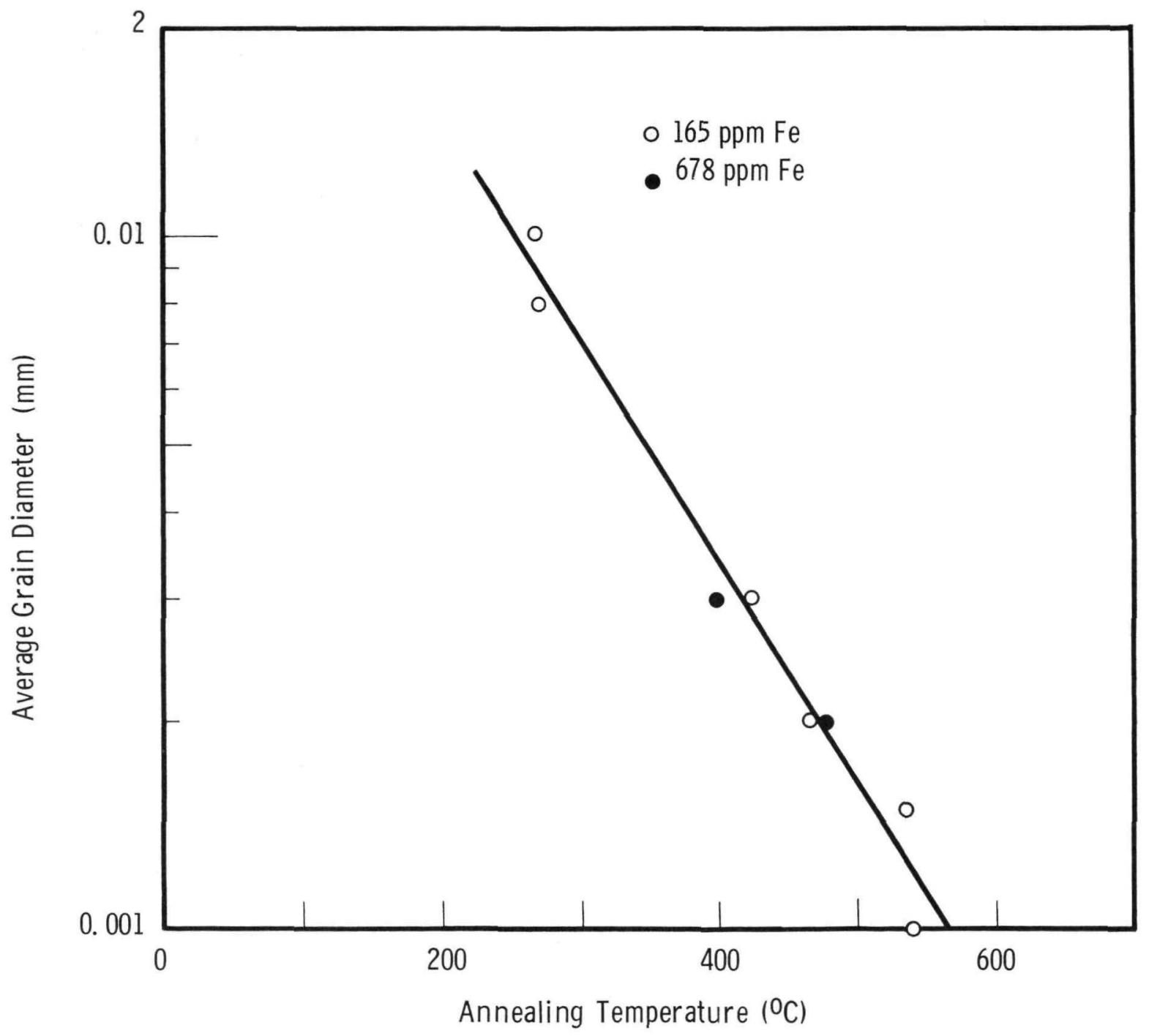

FIGURE 4

Relation Between Annealing Temperature and Grain Size of Plutonium at Quenched End of Jominy Specimen 


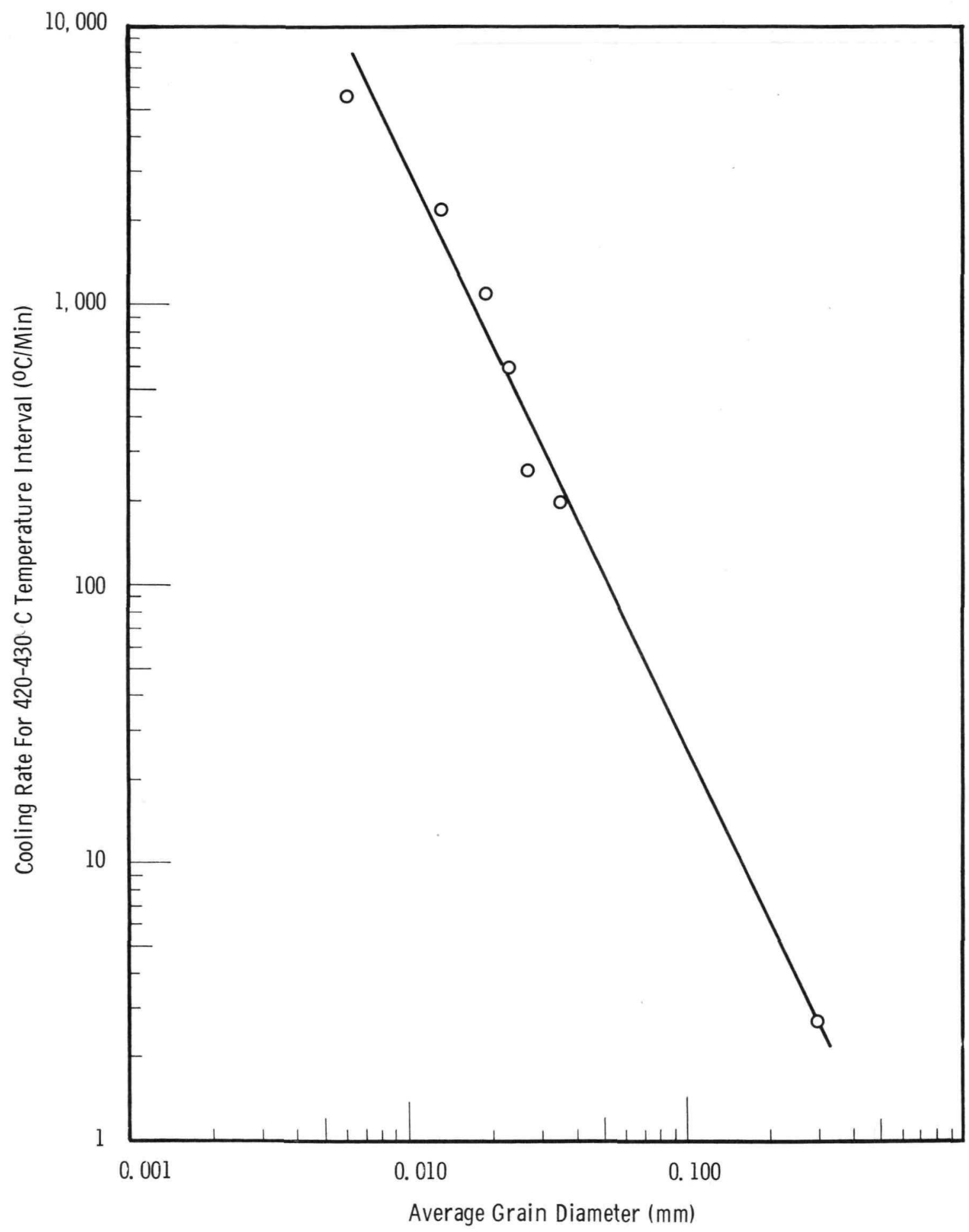

FIGURE 9

Relation Between Cooling Rate and $\mathrm{Pu}-\mathrm{Pu}_{6} \mathrm{Fe}$ Eutectic Network Size 


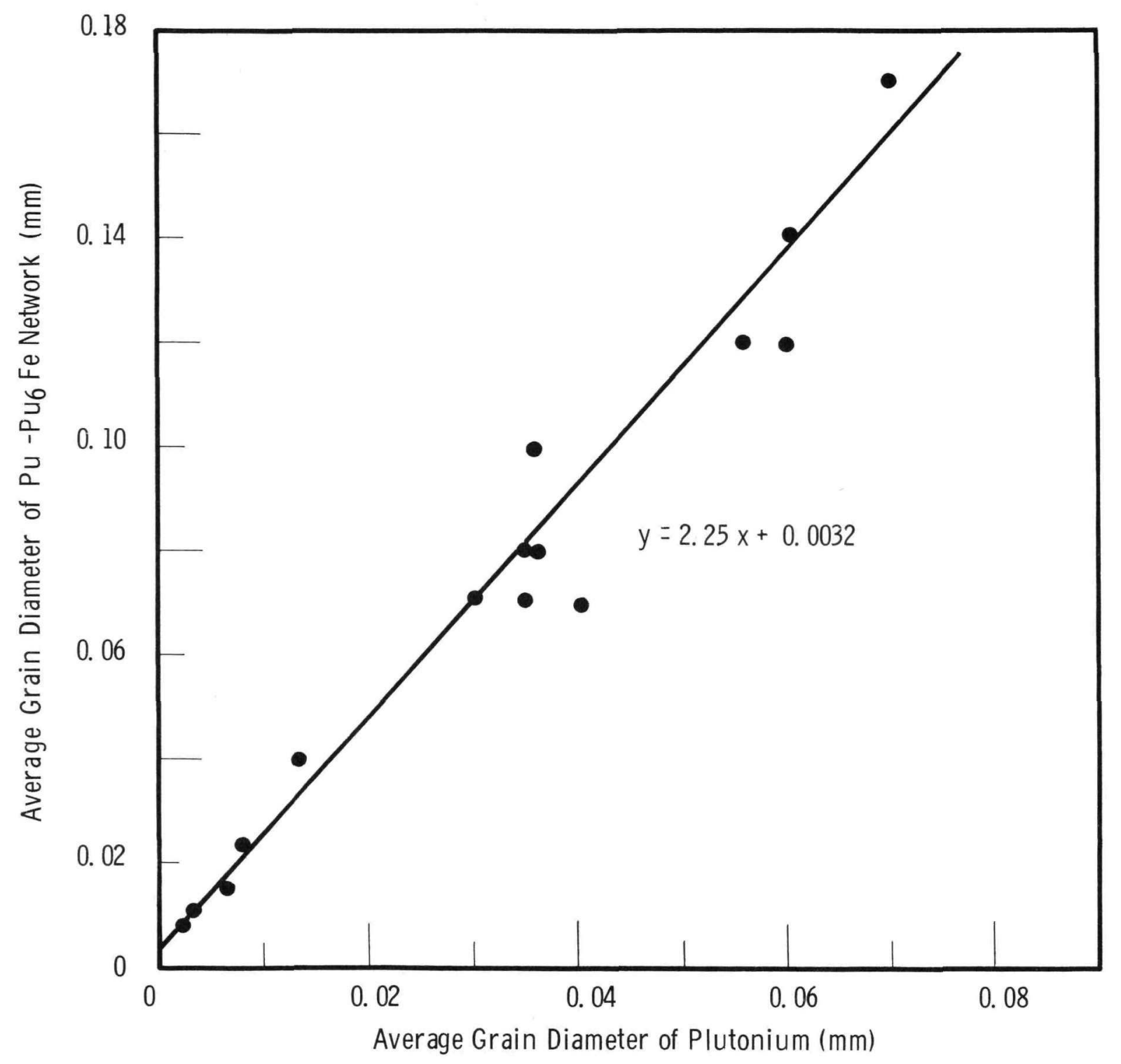

\section{FIGURE 17}

Relation Between Alpha Plutonium Grain Size and Grain Size of $\mathrm{Pu}-\mathrm{Pu}_{6} \mathrm{Fe}$ Eutectic Network 


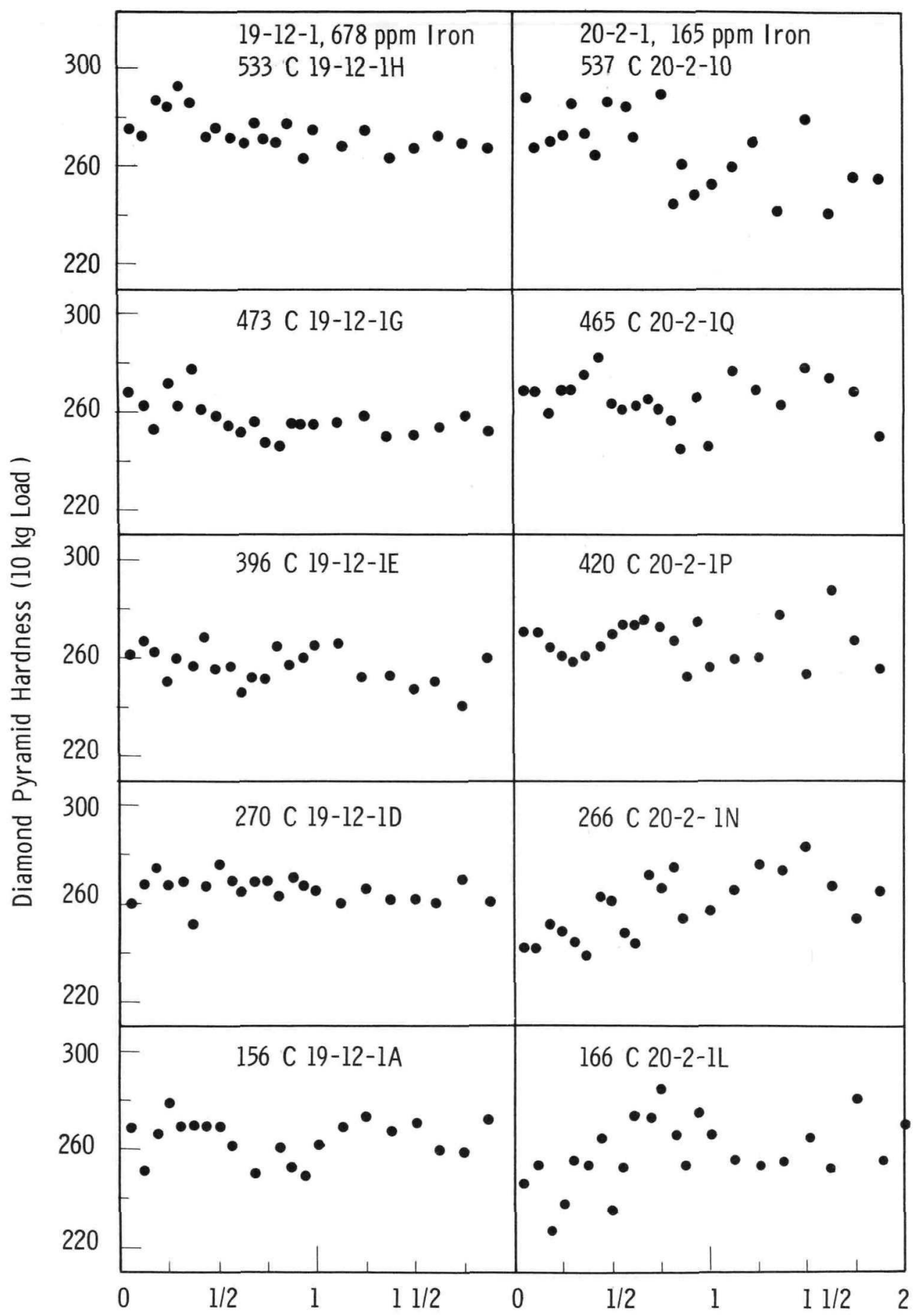

Distance from Quenched End Distance from Quenched End

FIGURE 20

Hardness Versus Distance from Quenched End of Jominy Bar 


\section{INTERNAL DISTRIBUTION}

Copy Number

\begin{tabular}{|c|c|}
\hline 1 & F. W. Albaugh \\
\hline 2 & A. E. Barber \\
\hline 3 & R. E. Bardsley \\
\hline 4 & C. H. Bloomster \\
\hline 5 & L. I. Brecke \\
\hline 6 & W. G. Browne \\
\hline 7 & J. B. Burnham \\
\hline 8 & S. H. Bush \\
\hline 9 & J. J. Cadwell \\
\hline 10 & D. F. Carroll \\
\hline 11 & T. D. Chikalla \\
\hline 12 & R. E. Falkoski \\
\hline 13 & T. F. Fisher \\
\hline 14 & M. D. Freshley \\
\hline 15 & H. R. Gardner \\
\hline 16 & W. J. Gartin \\
\hline 17 & W. S. Hartnett \\
\hline 18 & W. J. Hoffman \\
\hline 19 & H. H. Hopkins \\
\hline 20 & W. P. Ingalls \\
\hline 21 & Y. B. Katayama \\
\hline 22 & R. R. King, Jr. \\
\hline 23 & P. S. Kingsley \\
\hline 24 & R. K. Koler \\
\hline 25 & L. C. Lemon \\
\hline 26 & E. D. McClanahan \\
\hline 27 & L. H. McEwen \\
\hline 28 & J. V. McMaster \\
\hline 29 & L. G. Merker \\
\hline 30 & R. D. Nelson \\
\hline 31 & T. C. Nelson \\
\hline 32 & P. G. Pallmer \\
\hline 33 & H. M. Parker \\
\hline 34 & C. S. Powers \\
\hline 35 & M. N. Raile \\
\hline 36 & J. H. Rector \\
\hline 37 & W. T. Ross \\
\hline 40 & W. Sale \\
\hline 41 & R. E. Sharp \\
\hline $42-44$ & R. K. Sharp \\
\hline 45 & A. E. Smith \\
\hline 46 & R. W. Stewart \\
\hline 47 & E. O. Swain \\
\hline 48 & I. N. Taylor, Jr. \\
\hline 49 & J. M. Taylor \\
\hline
\end{tabular}


INTERNAL DISTRIBUTION (contd.)

Copy Number

$\begin{array}{ll}50 & \text { I. D. Thomas } \\ 51 & \text { W. B. Weihermiller } \\ 52 & \text { O. J. Wick } \\ 53 & \text { S. H. Woodcock } \\ 54 & \text { Record Center } \\ 55 & \text { 300 File Copy } \\ 56-76 & \text { Extra }\end{array}$

EXTERNAL DISTRIBUTION (Special)

Copy Number

77

78

HOO Technical Library

Los Alamos Scientific Laboratory

Attn: S. E. Bronisz

EXTERNAL DISTRIBUTION

No. of Copies

$\begin{aligned} & 3 \text { Aberdeen Proving Ground } \\ & 1 \text { Aerojet-General Corporation } \\ & 1 \text { Aerojet-General Nucleonics } \\ & 1 \text { Aeroprojects Incorporated } \\ & 2 \text { ANP Project Office, Convair, Fort Worth } \\ & 1 \text { Alco Products, Inc. } \\ & 1 \text { Allis-Chalmers Manufacturing Company } \\ & 1 \text { Allis-Chalmers Manufacturing Company, Washington } \\ & 1 \text { Allison Division-GMC } \\ & 10 \text { Argonne National Laboratory } \\ & 1 \text { Armour Research Foundation } \\ & 1 \text { Army Ballistic Missile Agency } \\ & 1 \text { AEC Scientific Representative, Belgium } \\ & 1 \text { AEC Scientific Representative, France } \\ & 1 \text { AEC Scientific Representative, Japan } \\ & 3 \text { Atomic Energy Commission, Washington } \\ & 4 \text { Atomic Energy of Canada Limited } \\ & 4 \text { Atomics International } \\ & 4 \text { Babcock and Wilcox Company } \\ & 2 \text { Battelle Memorial Institute } \\ & 1 \text { Beryllium Corporation } \\ & 1 \text { Bridgeport Brass Company } \\ & 1 \text { Bridgeport Brass Company, Adrian } \\ & 2 \text { Brookhaven National Laboratory } \\ & 1 \text { Brush Beryllium Company } \\ & 1 \text { Bureau of Mines, Albany } \\ &\end{aligned}$


EXTERNAL DISTRIBUTION (contd.)

\section{No. of Copies}

1

1

3

1

1

1

1

1

1

1

2

1

4

1

1

1

2

2

2

1

1

1

Bureau of Ships (Code 1500)

Carborundum Company

Chicago Operations Office

Chicago Patent Group

Clevite Corporation

Combustion Engineering, Inc.

Combustion Engineering, Inc. (NRD)

Convair-General Dynamics Corporation, San Diego

Defence Research Member

Denver Research Institute

Department of the Army, G-2

Dow Chemical Company (Rocky Flats)

duPont Company, Aiken

duPont Company, Wilmington

Frankford Arsenal

Franklin Institute of Pennsylvania

General Atomic Division

General Electric Company (ANPD)

General Electric Company, St. Petersburg

General Nuclear Engineering Corporation

Glasstone, Samuel

Gocdyear Atomic Corporation

Iowa State University

Jet. Propulsion Laboratory

Johns Hopkins University (ORO)

Knolls Atomic Power Laboratory

Los Alamos Scientific Laboratory

Los Alamos Scientific Laboratory (Sesonske)

M \& C Nuclear, Inc.

Mallinckrodt Chemical Works

Maritime Administration

Martin Company

Mound Laboratory

NASA Lew is Research Center

National Bureau of Standards

National Bureau of Standards (Library)

National Carbon Company

National Lead Company of Ohio

Naval Research Laboratory

New Brunswick Area Office

New York Operations Office

Northern Research and Engineering Corporation

Nuclear Development Corporation of America

Nuclear Materials and Equipment Corporation

Nuclear Metals, Inc.

Oak Ridge Institute of Nuclear Studies

Office of Naval Research 
EXTERNAL DISTRIBUTION (contd.)

No. of Copies

1

1

1

1

1

4

1

1

3

1

2

1

1

1

1

1

2

5

1

1

1

1

1

1

1

2

2

1

1

4

1

8

1

325
Office of Naval Research (Code 422)

Olin Mathieson Chemical Corporation

Ordnance Materials Research Office

Ordnance Tank-Automotive Command

Patent Branch, Washington

Phillips Petroleum Company (NRTS)

Picatinny Arsenal

Power Reactor Development Company

Pratt and Whitney Aircraft Division

Rensselaer Polytechnic Institute

Sandia Corporation, Albuquerque

Sandia Corporation, Livermore

Stevens Institute of Technology (Comstock)

Sylvania Electric Products, Inc.

Technical Research Group

Tennessee Valley Authority

Union Carbide Nuclear Company (ORGDP)

Union Carbide Nuclear Company (ORNL)

Union Carbide Nuclear Company (Paducah Plant)

USAF Project RAND

U. S. Geological Survey, Denver

U. S. Geological Servey, Menlo Park

U. S. Geological Survey, Washington

U. S. Naval Postgraduate School

U. S. Patent Office

University of California, Berkeley

University of California, Livermore

University of Puerto Rico

Watertown Arsenal

Westinghouse Bettis Atomic Power Laboratory

Westinghouse Electric Corporation

Wright Air Development Division

Yankee Atomic Electric Company

Office of Technical Information Extension 